\title{
Does Higher Business Education Champion Environmental Sustainability for Next Generation of Leaders? An Assessment of In-School Students and Alumni's Perspective
}

\author{
Minghui Yang1,2*, Jiawen Wang ${ }^{1}$, Fakhra Yasmin ${ }^{3}$ \\ IInternational Business School, Guangzhou City University of Technology, Guangzhou, \\ Guangdong 510800, People's Republic of China \\ ${ }^{2}$ Faculty of Informatics and Management, University of Hradec Kralove, Hradec Kralove 50003, Czech Republic \\ ${ }^{3}$ School of Education, South China Normal University, Guangzhou, Guangdong 510631, People's Republic of China
}

Received: 4 February 2021

Accepted: 12 April 2021

\begin{abstract}
Higher business education has become a crucial driver of change in achieving sustainable development because it can educate future leaders who champion environmental sustainability initiatives in the corporate world. Given that there is a gap between sustainability knowledge taught in school and what it practiced at the workplace, this study aims to assess in-school students (undergraduate seniors) and already graduate students (alumni)'s perception toward environmental sustainability that provides an exploratory lens to advance youngster's pro-environmental attitudes and practices. By administrating a survey questionnaire under the theory of planned behavior (TPB) model, 142 in-school students and 166 alumni from a China's university participated in a survey questionnaire. Overall results show that students ranked external referent groups (subjective norm) as the most important factor, followed by the personal beliefs (attitude) and perceived competence of engaging in the behavior (perceived behavioral control). Compared with the alumni, the in-school students have a more favorable perception of environmental sustainability. Though, the biggest perception gap between in-school students and alumni was observed in the subjective norm section where in-school students more often agreed to the importance of university administrators and professors as valid referent group in promoting greener issues. The study findings offer practical recommendations to educators and corporate leaders for further facilitating environmental sustainability.
\end{abstract}

Keywords: environmental sustainability, higher business education, students, alumni, theory of planned behavior

*e-mail: yangmh@gcu.edu.cn 


\section{Introduction}

The concept of sustainable development (SD) has continuously evolved and has been emphasized by the Higher Education Institutions (HEIs) for decades. To recognize the important role of HEIs within $\mathrm{SD}$, the United Nations Educational, Scientific and Cultural Organization (UNESCO) requires all relevant stakeholders including regulatory authorities, private sector, and the educational institutions to work together for achieving a more sustainable planet [1]. In recent years, the increased environmental degradation also gave rise to public concerns toward environmental sustainability, of which resources need to be conserved for future generations [2, 3]. The integration of environmental sustainability into higher education was initially highlighted by the United Nations (UN) in 1987, where HEIs play important role in solving global environmental problems [4]. Henceforth, several declarations, like the 1990 Talloires Declaration, the 1991 Halifax Declaration, the 1993 Swansea Declaration, and the 2001 Lüneburg Declaration, all aimed at better incorporating the environmental sustainability into curriculum [5]. Undoubtedly, education can shape students' value and belief system, potentially influencing their personal resource consumption pattern, and even managerial decisionmaking once they become business leaders [6].

Even if environmental sustainability is increasingly perceived as an important issue and individual's perception can differ substantially $[7,8]$, business students and practitioners more often agree to the importance of profitability which is a vital factor for firms to survive in a competitive market. In the Chinese context, executives would not traditionally exercise corporate social responsibility (CSR) practices because most of the Chinese firms still make efforts to maximize market shares and seek for economic advantages [9, 10]. Given that sustainability education could increase students' perceived legitimacy of environmental sustainability, Chinese HEIs is regarded as a facilitator in addressing the ever-increasing domestic environmental deterioration [11, 12]. Besides, future business leaders and managers can also benefit from the sustainability education, as they are more likely to champion corporate environmental sustainability initiatives $[13,14]$.

In recent years, there has been a growing number of HEIs that began to adopt SD initiatives in their campus planning, day-to-day operations, and curriculum development. Though, two critical problems have emerged with respect to business education for environmental sustainability. First, the core business courses like accounting, finance, marketing or management are usually less relevant to the environmental sustainability issues as compared to the courses in the fields of natural sciences [15]. Practically, modern enterprises may feel hard to balance their economic and environmental objectives because corporate environmental initiatives will consume valuable resources [16]. Second, students may not champion the environmental sustainability for future corporate decision-making, notwithstanding they are taught by sustainability courses and sensitive to environmental issues [17]. Simply put, a student may perceive environmental responsibility as important, yet such mindset may not reflect in their personal practices since they still consider sustainability is a minor issue and not quite necessary to be implemented in a realworld scenario [6].

While some recent studies investigate environmental sustainability from in-school students' perspective $[3,12,18-20]$, there is a dearth of research assessing alumni's perception. Blickley et al. [21] assert that a critical challenge of current HEIs is that skills taught in the classroom settings do not necessarily concur with the skills desired by the employees at the workplace. Given that alumni are recent graduated students while simultaneously having practical working experiences, they may understand the gap between sustainability knowledge taught in HEIs and what is practiced at the workplace $[22,23]$. Because of the important role of alumni, our study contributes to existing literature by comparing environmental sustainability perceived by alumni and by in-school students, and identifying underpinning reasons that cause the perceived gap among youngsters. Moreover, the existing literature is mostly focused on developed countries [19, 24], but only a few have considered HEIs' environmental sustainability in emerging economies like China, which have experienced an increasing number of polluted production and environmental accidents in recent decades [25-27]. We contribute to fill this gap by conducting a survey research with respondents coming from a Chinese university, namely Guangzhou College of South China University of Technology (GCU), which is one of the top 10 private HEIs in China.

The aim of this study is to assess in-school students and alumni's perception toward environmental sustainability, and investigate the factors that influence students' intentions to perform environmental sustainability behaviors. We also offer recommendations to further facilitate youngsters' environmental attitudes and practices in the Chinese context. The Theory of Planned Behavior (TPB) is utilized as theoretical basis, of which the existing social science literature has widely employed TPB as a tool to understand a variety of behaviors and predict an individual's decision to conduct or follow a particular behavior [28, 29]. There are three components used in designing the survey instrument of this study including attitude (i.e., whether students are in favor of engaging in environmental sustainability), subjective norm (i.e., how much students feel pressure from university administration and professors for engaging in environmental sustainability), and perceived behavioral control (i.e., whether students perceive themselves as having the competence to engage in environmental sustainability). 


\section{Literature Review}

\section{Higher Education for Environmental Sustainability}

\section{Environmental Sustainability in Higher Business Education}

Higher education has met strong institutional pressures that HEIs need to behave in socially responsible ways, and effectively involve in environmental sustainability issues $[30,31]$. It can be reflected by a growing number of worldwide declarations like the 1972 Stockholm Declaration, the 1977 Tbilisi Declaration, the 1990 Talloires Declaration, the 1991 Halifax Declaration, the 1993 Kyoto Declaration and the 1993 Swansea Declaration [4, 32, 33]. Besides these global declarations, HEIs' self-defined policies also play an important role in tackling environmental issues such as green campus operations and sustainability education [34]. Nevertheless, there is still a gap between green knowledge and real educational actions that calls for more studies on exploring pedagogy for sustainability in HEIs [35-39].

In recent years, corporations have started to incorporate environmental elements into decision making through CSR strategies, and sought to achieve a balance between economic and environmental objectives [40, 41]. As such, business school is central to educate future business leaders and managerial decision makers about sustainability knowledge and practical skills needed in the career [42]. To better facilitate higher business education for sustainability, the UN launched an initiative in 2007, termed as the Principles for Responsible Management Education (PRME), consisting of six principles including purpose, values, method, research, partnership and dialogue [43]. Some international bodies of higher business education, such as the European Foundation for Management Development (EFMD), the Association to Advance Collegiate School of Business (AACSB) and the Aspen Institute's Business and Society Program also actively promoted environmental sustainability in the last decade $[41,44,45]$.

Nevertheless, business schools are still challenged by the ineffective and inadequate educational integration toward environmental sustainability [19, 46-49]. Based on the report of the Higher Education Funding Council for England (HEFCE), the majority of business graduates failed to contribute to social and economic development in a sustainable manner [50]. According to Ceulemans et al. [51], teachers in business schools have insufficient awareness of SD, and the top-down hierarchy of universities is not in favor of promoting campus sustainability. Unlike majors in natural sciences which encourage a transformative learning process, business majors are subject to social science with less training in critical thinking, system thinking, and openness to alternative views [6]. This transmissive learning process is organized by a standardization model where students have less opportunities to develop new ways of understanding regarding the role and practices of the business, and therefore are incapable to comprehend the meta-issues in sustainability $[5,6,52$, 53].

In fact, the majority of students still perceive that their behaviors would not make any significant impact on the environment [54, 55]. Even if business schools make efforts to promote SD and include environmental issues in pedagogical activities, an inconsistency between perceived knowledge and personal actions will emerge because a student with strong sustainability commitment does not guarantee that he or she is persuaded to integrate sustainability issues into future managerial decision-making [18]. Environmental education can enhance students' sensitivity toward environmental preservation to some extent, but it is just a starting point for green practices in the real life [6, 17]. In order to increase individuals' perceived legitimacy, it becomes vital to explore the factors that effectively influence students' pro-environmental attitudes and intended sustainability behaviors $[6,19,56]$.

\section{Environmental Sustainability in Chinese HEI}

Western countries are the first movers of environmental sustainability education, whilst China do not pay attention to environmental education until 1972 when the role of HEIs in SD was initially discussed in the Stockholm Declaration $[57,58]$. In the past two decades, some of Chinese HEIs began to promote campus environmental management. For instance, Tsinghua University was the first HEIs in mainland China to declare sustainability goal for achieving "Green University" in 1998 [3, 59]. This concept was further emphasized by the China Green University Network (CGUN) established in Tongji University in 2011, with a total of eight public universities and two research institutions collectively declared that they would work hard to promote SD goals (SDG) in higher education [60].

Nevertheless, HEIs in China confront various challenges while integrating environmental sustainability into campus operations and student's education. First, environmental education is still new to most of university administrators in China, therefore requiring a cross-functional approach, such as establishing an interdisciplinary team with qualified personnel, and perquisite training to students, staff and faculty [61]. Second, administrators may feel reluctant to allocate financial resources to environmental practices because they tend to focus more on profitable opportunities and traditionally perceive sustainability education as a low-return investment. Third, students still consider that environmental sustainability contradicts with the core business operations and environmental problems need to be solved after people get rich [58]. 
Perceived Legitimacy and the Theory of Planned Behavior (TPB)

Students' opinions toward the importance of environmental sustainability can differ substantially, leading to a fact that educators of HEIs may struggle to foster the environmentally friendly mindset in their students [19]. Adopting or refuting environmental sustainability depends on the extent to which the students consider it legitimate. According to Suchman [62], legitimacy is a generalized perception that a set of behaviors are proper and desirable within social norms, values, and beliefs. When particular actions or rules are in line with the social order, individuals will perceive them as widely shared, and have a tendency to demonstrate corresponding behavior [63]. Accordingly, legitimacy is a socially cognitive process, reflected by a mental conversation between individuals' internal view of what matter to them and what other relevant people think. This is similar to Ajzen's [29] Theory of Planned Behavior (TPB) which suggests that the possibility of individuals' intended behavior depends upon their attitude (internal belief regarding the right course of action), subjective norm (external pressures generated from the referent groups), and perceived behavior controls (self-competence of taking actions and making related controls).

The TPB model is a social-cognitive model, which aids researchers to understand diverse behaviors and interprets how an individual's particular behavior is determined by his or her intention to engage in that behavior [29]. The TPB was developed by social psychologist and has been widely used in existing social science literature [28]. In terms of environmental sustainability domain, the TPB model was commonly applied to investigate environmental behavior including recycling [64], garbage reduction [65], green purchasing [66, 67], environmental activism [68] and high-school students' pro-environmental practices [69].

The first component of the TPB, termed attitude, refers to whether an individual is in favor of performing a particular behavior [29]. A positive attitude leads to a stronger intention to engage in the behavior. For instance, favorable attitude on environmental sustainability can reflect in garbage reduction [65], and increased green purchasing [66, 67]. The second component is subjective norm, concerning perceived pressures from referent groups that determine an individual's own behavior [29]. It aims to measure an individuals' compliance to their perception of what these referent groups expect of them [70]. de Leeuw et al. [69] suggest that subjective norm has positive impact on personal engagement in pro-environmental behaviors. Swaim et al. [19] also find that professors, business leaders, and politicians are crucial subjective norm that influences students' intention toward environmental sustainability practices. The third component, namely perceived behavioral control, relates to an individual's perceived ability to conduct the behavior [29]. Higher level of perceived behavior control indicates that a person consider himself or herself occupying sufficient resources (knowledge, ability and control) and therefore has a higher likelihood to carry out the behavior [71]. The TPB model is shown in Fig. 1.

Thomas and Lamm [72] contend that elements of perceived legitimacy can be integrated into TPB model. One of the legitimacy elements, termed propriety, can correspond to the TPB's attitude component [6]. Propriety is an internal element, referring to an individual's perception that the specific rules and actions are desirable, appropriate and useful [63]. Another element of legitimacy, called validity, can be mapped to the TPB's subjective norm section [6]. It is an external element, relating to a person's belief that he or she is obligated to respond to social pressures and follow social norms regardless of personal sense of propriety [63]. Validity is a collective form of legitimacy with two external sources, authorization and endorsement. The first source, authorization, arises when legitimacy is conferred by an authority or individuals' superior who holds a higher position in the hierarchy. The second source, endorsement, occurs when the support of particular rules or actions comes from either peers

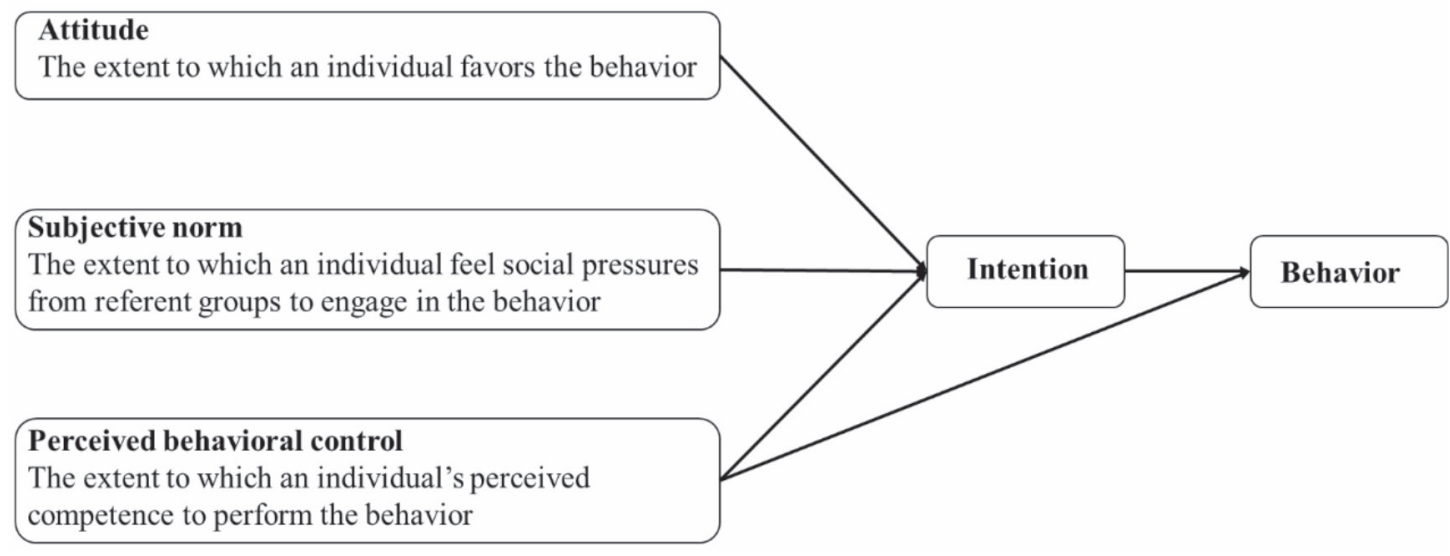

Fig. 1. The TPB model. 


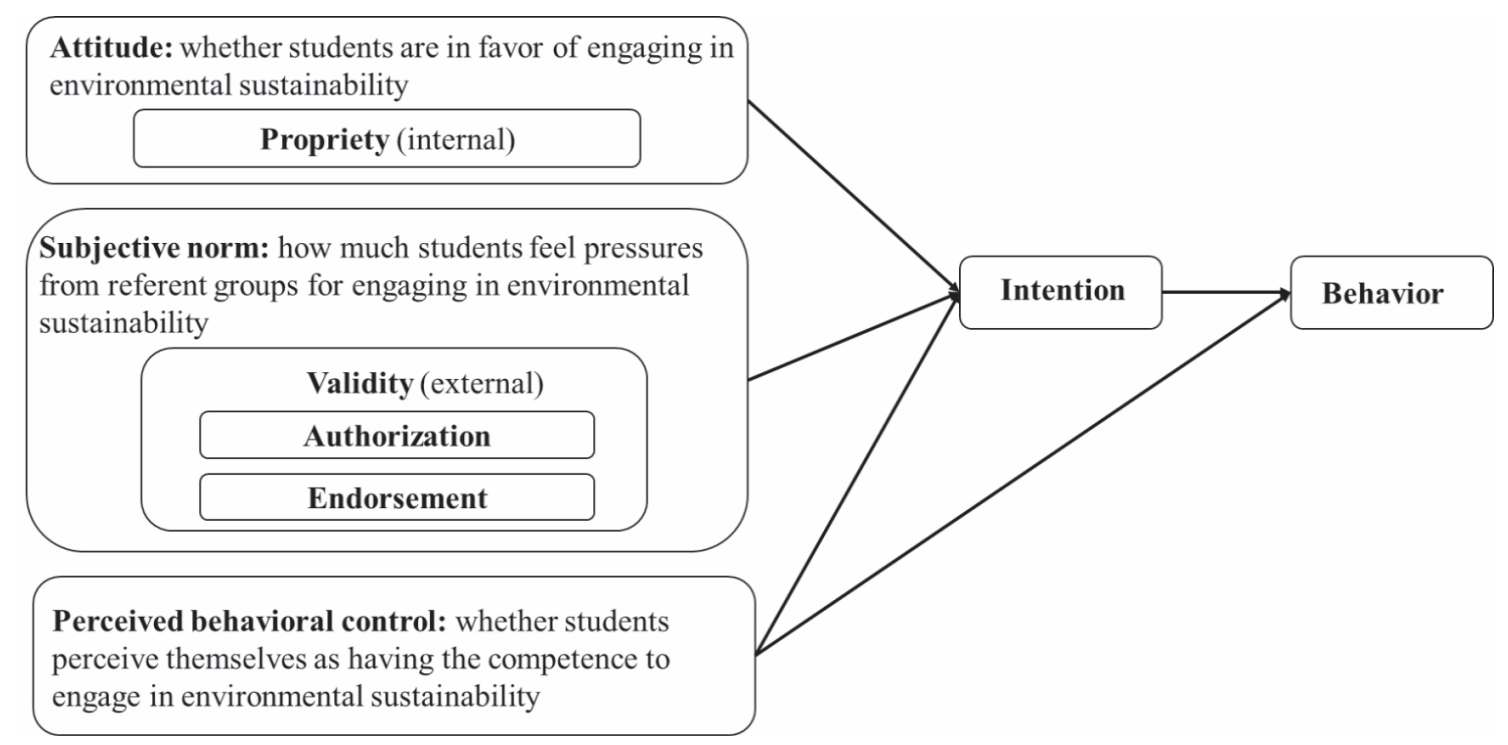

Fig. 2. The integration of elements of legitimacy into the TPB model.

or the people with similar or lower position in the hierarchy [73].

In this study, we employ the TPB model to design the survey instrument. The perceived legitimacy is applied as a theoretical construct to further explain students' personal evaluation of environmental sustainability and their perceived external social pressures for sustainability practices. The integrated model with a combination of legitimacy elements and the TPB is shown in Fig. 2.

\section{Materials and Methods}

\section{Study Area}

A private university in China, Guangzhou College of South China University of Technology (GCU), was chosen to investigate the perception of environmental responsibility from in-school senior undergraduate students and alumni's perceptive. GCU is one of the top three private universities in Guangdong province, and also among the top ten private HEIs countrywide. It is located in Huadu district of Guangzhou, the third largest city of China, at a distance of about 10 kilometers from the airport and 40 kilometers from the city center. With a total of 41 undergraduate programs within 13 schools, GCU has over 22,000 students and provides education in the field of Business \& Economics, Engineering and Social Sciences.

There are two reasons making GCU as an important study area of current study. First, given that GCU and other Chinese private HEIs need to raise their own funds, they always have different SD strategies and campus sustainability practices as compared with public HEIs which are fully funded by the nation [3]. Shedding light on private HEIs becomes significant as they are newly emerging SD participants, while the concept of "green university" has already been anchored in Chinese public HEIs' policy for two decades [59]. Second, Guangdong province, of which GCU geographically locates in, is the most developed region and important economic and trade hub in China. The relatively high living standard leads to greater public expectation upon good quality of life (e.g., environmental quality). Thus, the Guangdong province becomes a featured area in investigating environmental sustainability of HEIs.

In terms of incorporating SD into campus policy, GCU mandates that all the undergraduate programs shall include at least one sustainability course in curricula, or link sustainability issues to routine pedagogical activities. Moreover, the Rector's Office actively motivates faculty members to conduct research towards sustainability subjects, and provides monetary incentives to scientific projects related to environmental sustainability. To manage the survey without critical ethical concern, we sent request to the Deanship Office of International Business school. The approval was received in mid-April, 2020.

\section{Survey Instrument}

The survey instrument is organized as a selfadministered questionnaire in both Simplified Chinese and English versions. The purpose of an English version is to avoid misconception of language expressions. In fact, the majority of respondents may feel adaptable to complete a bilingual questionnaire because business students of GCU have to undertake intensive English courses, therefore they have acceptable English reading skills. The construct of the survey is theoretically based on the TPB model, while the layout of questions is consistent with Emanuel and Adams [18] and Wang et al. defined format [3]. The survey comprises of three sections; attitude, subjective norm, and perceived behavioral control. The attitude section, comprises 
of three questions, assesses whether a student is in favor of engaging in environmental responsibility. The second section, subjective norm, evaluates the extent to which a student feels pressures from referent groups for engaging in environmentally responsible behavior. Three external groups were involved including university administration, faculty and professors, and business leaders and colleagues. The third section is perceived behavioral control which measures whether a student perceives himself or herself as having the ability to engage in environmental sustainability.

The questionnaire was based on a five-point Likert scale. Students were asked to respond to a sliding scale, ranging from 1 (represent strongly agree) to 5 (represent strongly disagree). Two rigidly structured multiple-choice questions were additionally included in the perceived behavioral control section, where students were required to select the most suitable option from lists of four items that they do or do not associate with environmental responsibility. To ensure the validity of the questionnaire, two professors of business administration and one post-doctoral researcher of pedagogy were invited for preliminarily review of the content and assess whether the goal of the questionnaire was met and the questions were articulated in a proper manner. Some modifications were made in the light of experts' comments and suggestions. The improved version of questionnaire was then delivered to two small groups of students including 13 in-school senior students and 12 alumni, in order to check whether the descriptions of phrases and sentences are concise and straightforward. Consequently, some adjustments were made based on the feedback of pilot testing. Hence, the final version of the questionnaire was valid and accurate. The full form of the questionnaire in shown in Appendix Table A.1.

The questionnaire was designed, distributed and collected through an online survey tool, namely Sojump (http://www.sojump.com), which is a commonly used electronic survey platform in China [74]. Providing user-friendly survey tools such as questionnaire formation, data collection, and result analysis, Sojump has apparent advantages like simple, accessible, and inexpensive [75]. The questionnaire was available online on March 2020 and could be accessed at the following link: https://www.wenjuan.com/s/uQJbeaQ/. On average, it took less than five minutes for the students to finish the questionnaire.

\section{Sample}

The questionnaire was administrated to the respondents via smart mobile phone. As WeChat is the most widely and frequently used social communication tool in China which enables respondents to conveniently complete the questionnaire in their personal smart phones [75], we directly sent the questionnaire to respondents' WeChat account. To engage more students in the survey, each respondent received a request to forward the link of questionnaire to their schoolmates. The data screening was firstly carried out on the basis of the following exclusion rules: logical mistakes within the answers; repeated IP address, and the same answers for consecutive questions. After excluding 23 invalid questionnaires, we finally came up with a total of 308 questionnaires, with 142 respondents from the inschool senior students, and 166 respondents from the alumni, respectively. All respondents were currently studying or have graduated from International Business School of GCU, with a business major in accounting, or economics and trade. We confirmed that the participation in the survey was voluntary for our respondents, and all the collected information was kept confidential.

\section{Statistical Analysis}

The statistical analysis of the data was carried through by using Sojump and SPSS 20.0 software. Descriptive statistics was automatically performed via the inherent statistical function of Sojump. The Pearson's chi-square statistic was conducted using SPSS 20.0, to analyze whether the distribution of demographic characteristics and survey questions is statistically different to one another. The T-test was also performed to examine the statistical significance in the mean values of all sections of the questionnaire among respondents.

\section{Results}

\section{Sample Characteristics}

The demographic characteristics of the respondents are shown in Table 1. The majority of respondents are female, representing $65.5 \%$ of the in-school senior students and $57.8 \%$ of alumni. Regarding the major, about $72.5 \%$ of the in-school seniors were studying economics and trade, and $27.5 \%$ of them were studying accounting majors. Of the alumni participants, $53.6 \%$ of them were majoring in economics and trade, and $46.4 \%$ in accounting.

Table 1. Demographics characteristics of respondents.

\begin{tabular}{|c|c|c|}
\hline Variable & $\begin{array}{c}\text { In-school senior } \\
\text { students }\end{array}$ & Alumni \\
\hline \multicolumn{3}{|c|}{ Gender } \\
\hline Male & $49(34.5 \%)$ & $70(42.2 \%)$ \\
\hline Female & $93(65.5 \%)$ & $96(57.8 \%)$ \\
\hline \multicolumn{3}{|c|}{ Major } \\
\hline Accounting & $39(27.5 \%)$ & $77(46.4 \%)$ \\
\hline Economics and Trade & $103(72.5 \%)$ & $89(53.6 \%)$ \\
\hline
\end{tabular}




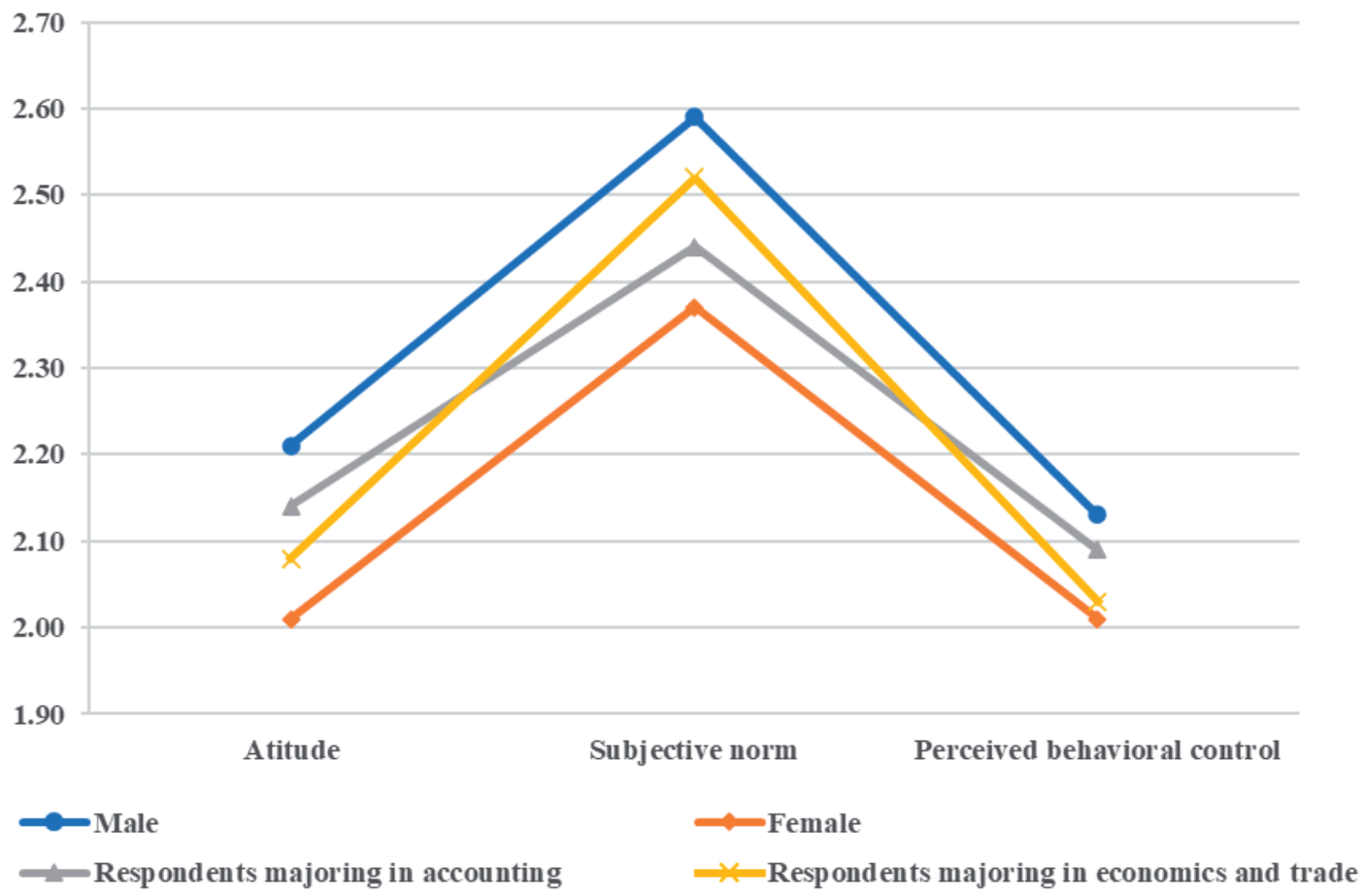

Fig. 3. Environmental sustainability perceived by the respondents with different gender and major of study.

When comparing respondents' perception of environmental sustainability with different gender and major of study, the results shown in Fig. 3 demonstrate that female students have a lower mean value of fivepoint Likert scale score, and therefore have a favorable perception than male students toward the three evaluation sections of environmental sustainability. Likewise, students majoring in accounting share a similar level of perception with students majoring in economics and trade.

The correlation matrix for variables of environmental sustainability is shown in Table 2 . The results indicate than all environmental sustainability sections including attitude, subjective norms and perceived behavior control are significantly and positively correlated to each other.

\section{Attitude}

The section of attitude aims to investigate respondents' personal feeling toward environmental sustainability and their likelihood of protecting the environment and minimizing potential harm to the environment. The results shown in Table 3 reveal that a majority of the in-school senior students and alumni show concern for the environment, with a percentage of $60.56 \%$ and $70.48 \%$ respectively. Even so, more in-school seniors than alumni have relatively neutral and negative point of view. When asked whether the environmental protection is more important than economic growth, less than half of the in-school seniors $(45.07 \%)$ and alumni (40.36\%) support such opinion.

Table 2. Correlations among variables of environmental sustainability.

\begin{tabular}{|c|c|c|c|}
\hline Variable & Attitude & Subjective norm & Perceived behavior control \\
\hline \multicolumn{3}{|c|}{ In-school senior students (N=142) } \\
\hline Attitude & 1 & & \\
\hline Subjective norm & $0.540^{* * *}$ & 1 & 1 \\
\hline Perceived behavior control & $0.319^{* * *}$ & $0.428^{* *}$ & \\
\hline \multicolumn{5}{|c|}{ Alumni $(\mathrm{N}=166)$} \\
\hline Attitude & 1 & 1 & 1 \\
\hline Subjective norm & $0.493^{* *}$ & $0.596^{* * *}$ & \\
\hline
\end{tabular}

Note: $* * *$ and $* *$ indicate significance at 0.05 and 0.01 levels. 
Table 3. Attitude towards environmental sustainability.

\begin{tabular}{|c|c|c|c|c|c|c|c|c|}
\hline \multirow{2}{*}{ Questions related to attitude } & \multicolumn{2}{|c|}{$\begin{array}{c}\text { Strongly agree or } \\
\text { Agree }\end{array}$} & \multicolumn{2}{|c|}{ Neutral } & \multicolumn{2}{|c|}{$\begin{array}{c}\text { Strongly disagree or } \\
\text { Disagree }\end{array}$} & \multirow{2}{*}{$\chi^{2}$} & \multirow{2}{*}{$\rho$} \\
\hline & $\begin{array}{c}\text { In-school } \\
\text { senior students }\end{array}$ & Alumni & $\begin{array}{c}\text { In-school } \\
\text { senior students }\end{array}$ & Alumni & $\begin{array}{c}\text { In-school } \\
\text { senior students }\end{array}$ & Alumni & & \\
\hline $\begin{array}{l}\text { I am quite concerned at present } \\
\text { about the wasteful consumption } \\
\text { of natural resources and the de- } \\
\text { struction/pollution of the } \\
\text { environment }\end{array}$ & $60.56 \%$ & $70.48 \%$ & $27.46 \%$ & $21.08 \%$ & $11.98 \%$ & $8.44 \%$ & 12.03 & $<0.01$ \\
\hline $\begin{array}{l}\text { I believe that the protection of the } \\
\text { environment is more important } \\
\text { than economic growth }\end{array}$ & $45.07 \%$ & $40.36 \%$ & $40.85 \%$ & $31.33 \%$ & $14.08 \%$ & $28.31 \%$ & 16.93 & $<0.01$ \\
\hline $\begin{array}{l}\text { I believe that we must conserve } \\
\text { our resources for future } \\
\text { generations of people }\end{array}$ & $75.35 \%$ & $69.28 \%$ & $23.94 \%$ & $18.67 \%$ & $0.71 \%$ & $12.05 \%$ & 7.45 & $<0.05$ \\
\hline
\end{tabular}

Besides, more alumni (28.31\%) than in-school seniors (14.08\%) disagree that the environmental preservation is more crucial than the bottom-line business affairs. In terms of the willingness to conserve resources for future generations, nearly two-third of the in-school seniors (75.35\%) and alumni (69.28\%) believe that it is necessary to preserve the environment for future generations. Though, very few in-school seniors $(0.71 \%)$ disagree with the need of conserving resources for the future. Overall, in-school seniors share similar attitude with alumni that environmental sustainability should be given priority.

\section{Subjective Norm}

Given that the external groups like university administrators, professors, and business leaders may shape students' beliefs toward environmental sustainability to some extent, the subjective norm section measures the degree of social pressure the students feel from these referent groups, and the extent of their willingness to conform to what external influencers expect of them. Three groups of influencers are investigated including university administration, faculty and professors, and business leaders and colleagues. The results depicted in Table 4 indicate that more in-school senior students than their alumni counterpart believe that university administration is one of the vital influencers. Specifically, the majority of the in-school seniors $(60.56 \%)$ agree that university is obligated to involve in environmental sustainability in their campus mission and day-to-day operations. While only one-third of the alumni (37.95\%) have similar opinion. Though, a larger proportion of the inschool seniors $(61.27 \%)$ than alumni $(47.59 \%)$ agree that university should contribute to energy conservation. Likewise, over two-third of the in-school seniors $(69.72 \%)$ believe that it is necessary for the university to recycle the solid waste, whilst less than half of the alumni $(44.58 \%)$ agree with the university's role in recycling. Nearly half of the in-school seniors (45.77\%) and one-third of the alumni (33.73\%) acknowledge that university is responsible for implementing water conservation practices. Regarding green transportation within or between campuses, about two-fifths of the in-school seniors $(43.66 \%)$ and one-third of the alumni (33.13\%) express their support to this endeavor.

In terms of the extent to which faculty and professors impact students' perception, about two-thirds of the in-school senior students $(66.20 \%)$ believe that an integration between environmental sustainability and the content of courses should be promoted. While only a third of the alumni $(37.95 \%)$ agree with the importance of environmental education. In respect of the curriculum, a large proportion of the in-school seniors $(60.56 \%)$ and half of the alumni $(50.60 \%)$ acknowledge that faculty should provide some courses that address topics related to environmental sustainability. When asked whether the research of environmental sustainability is needed or not, there are more in-school seniors $(57.04 \%)$ than alumni $(39.76 \%)$ which agree that faculty and professors should contribute toward sustainability research.

The last group of influencers is business leaders and colleagues. Practitioners can impact students' perception and behavior under the scope of corporate missions and objectives. As such, it is important to understand how students consider the role of the firm in performing environmental responsibility. A majority of the in-school senior students $(65.49 \%)$ and alumni $(62.05 \%)$ believe that companies need to represent themselves as environmentally friendly enterprises. About $64.09 \%$ of the in-school seniors and $54.81 \%$ of the alumni agree that companies should make efforts to conserve the use of energy and resources. Nevertheless, more than half of the in-school seniors $(58.45 \%)$ and alumni $(58.43 \%)$ acknowledge that everyone in the company needs to support sustainable solutions to environmental problems.

In light of the aforementioned results, we conclude that in-school senior students more often agree to the 
Table 4. Subjective norm toward environmental sustainability.

\begin{tabular}{|c|c|c|c|c|c|c|c|c|}
\hline \multirow{2}{*}{$\begin{array}{l}\text { Questions related to subjective } \\
\text { norm }\end{array}$} & \multicolumn{2}{|c|}{$\begin{array}{c}\text { Strongly agree or } \\
\text { Agree }\end{array}$} & \multicolumn{2}{|l|}{ Neutral } & \multicolumn{2}{|c|}{$\begin{array}{l}\text { Strongly disagree or } \\
\text { Disagree }\end{array}$} & \multirow{2}{*}{$\chi^{2}$} & \multirow{2}{*}{$\rho$} \\
\hline & $\begin{array}{c}\text { In-school } \\
\text { senior students }\end{array}$ & Alumni & $\begin{array}{c}\text { In-school } \\
\text { senior students }\end{array}$ & Alumni & $\begin{array}{c}\text { In-school } \\
\text { senior students }\end{array}$ & Alumni & & \\
\hline \multicolumn{9}{|c|}{ University administration } \\
\hline $\begin{array}{l}\text { University should engage en- } \\
\text { vironmental sustainability into } \\
\text { campus planning, development } \\
\text { and day-to-day operations }\end{array}$ & $60.56 \%$ & $37.95 \%$ & $21.83 \%$ & $40.36 \%$ & $17.61 \%$ & $21.69 \%$ & 29.37 & $<0.01$ \\
\hline $\begin{array}{l}\text { University should contribute to } \\
\text { energy conservation practices }\end{array}$ & $61.27 \%$ & $47.59 \%$ & $16.90 \%$ & $41.57 \%$ & $21.83 \%$ & $10.84 \%$ & 7.76 & $<0.05$ \\
\hline $\begin{array}{l}\text { University should contribute to } \\
\text { recycling of solid waste }\end{array}$ & $69.72 \%$ & $44.58 \%$ & $26.76 \%$ & $34.94 \%$ & $3.52 \%$ & $20.48 \%$ & 6.94 & $<0.05$ \\
\hline $\begin{array}{l}\text { University should contribute to } \\
\text { water conservation practices }\end{array}$ & $45.77 \%$ & $33.73 \%$ & $35.21 \%$ & $43.98 \%$ & $19.01 \%$ & $22.29 \%$ & 11.37 & $<0.01$ \\
\hline $\begin{array}{l}\text { University should contribute to } \\
\text { green transportation program }\end{array}$ & $43.66 \%$ & $33.13 \%$ & $38.73 \%$ & $39.16 \%$ & $17.61 \%$ & $27.71 \%$ & 9.81 & $<0.01$ \\
\hline \multicolumn{9}{|c|}{ Faculty and professors } \\
\hline $\begin{array}{c}\text { Professors need to integrate some } \\
\text { environmental sustainability } \\
\text { aspects into courses }\end{array}$ & $66.20 \%$ & $37.95 \%$ & $20.42 \%$ & $28.92 \%$ & $13.38 \%$ & $33.13 \%$ & 18.31 & $<0.01$ \\
\hline $\begin{array}{l}\text { Faculty need to offer courses } \\
\text { which address topic related to } \\
\text { environmental sustainability }\end{array}$ & $60.56 \%$ & $50.60 \%$ & $22.54 \%$ & $24.70 \%$ & $16.90 \%$ & $24.70 \%$ & 13.59 & $<0.01$ \\
\hline $\begin{array}{c}\text { Faculty need to promote research } \\
\text { related to environmental } \\
\text { sustainability }\end{array}$ & $57.04 \%$ & $39.76 \%$ & $27.47 \%$ & $32.53 \%$ & $15.49 \%$ & $27.71 \%$ & 13.09 & $<0.01$ \\
\hline \multicolumn{9}{|c|}{ Business leaders and colleagues } \\
\hline $\begin{array}{l}\text { Company should represent itself } \\
\text { as environmentally friendly }\end{array}$ & $65.49 \%$ & $62.05 \%$ & $21.13 \%$ & $24.70 \%$ & $13.38 \%$ & $13.25 \%$ & 7.05 & $<0.05$ \\
\hline $\begin{array}{c}\text { Company should contribute to } \\
\text { energy and resource conservation } \\
\text { practices }\end{array}$ & $64.09 \%$ & $54.81 \%$ & $20.42 \%$ & $31.33 \%$ & $15.49 \%$ & $13.86 \%$ & 7.40 & $<0.05$ \\
\hline $\begin{array}{l}\text { Everyone in the company should } \\
\text { support sustainable solutions to } \\
\text { environmental problems }\end{array}$ & $58.45 \%$ & $58.43 \%$ & $26.06 \%$ & $22.29 \%$ & $15.49 \%$ & $19.28 \%$ & 6.83 & $<0.05$ \\
\hline
\end{tabular}

crucial role of university administration and professor as compared to alumni. While both in-school seniors and alumni have similar views toward the role business leaders in promoting environmental sustainability.

\section{Perceived Behavioral Control}

The section of perceived behavioral control examines students' perceived ability (knowledge, control) to engage in environmental sustainability. The results shown in Table 5 consist of two aspects; students' actual knowledge, and their willingness to participate in the environmental sustainability practices. Respondents were firstly asked to assess how well they know about environmental sustainability. More than half of the in-school senior students (56.34\%) and slightly less than half of the alumni (46.39\%) declare that they have sufficient knowledge of this issue.
We then provided multiple choice questions where respondents need to select the most suitable choice from a list of five options. $62.68 \%$ of the in-school seniors and $57.23 \%$ of the alumni correctly chose the term related to environmental sustainability topic. When the students were asked to select the term irrelevant to environmental sustainability, more alumni (76.51\%) than in-school seniors $(73.24 \%)$ chose the correct option.

Subsequently, students' willingness to participate in environmental sustainability practices was examined. Nearly three-quarters of the in-school seniors (76.06\%) and alumni $(75.90 \%)$ state that they will use recycling. In terms of whether they will adapt energy conservation practices, more in-school seniors $(74.65 \%)$ answered in affirmative as compare to alumni (66.26\%). Moreover, $75.35 \%$ of the in-school seniors and $70.48 \%$ of the alumni agree with the use of environmentally friendly 
Table 5. Perceived behavioral control toward environmental sustainability.

\begin{tabular}{|c|c|c|c|c|c|c|c|c|}
\hline \multirow{2}{*}{$\begin{array}{l}\text { Questions related to perceived } \\
\text { behavioral control }\end{array}$} & \multicolumn{2}{|c|}{$\begin{array}{c}\text { Strongly agree or } \\
\text { Agree }\end{array}$} & \multicolumn{2}{|l|}{ Neutral } & \multicolumn{2}{|c|}{$\begin{array}{l}\text { Strongly disagree or } \\
\text { Disagree }\end{array}$} & \multirow{2}{*}{$\chi^{2}$} & \multirow{2}{*}{$\rho$} \\
\hline & $\begin{array}{c}\text { In-school } \\
\text { senior students }\end{array}$ & Alumni & $\begin{array}{l}\text { In-school } \\
\text { senior students }\end{array}$ & Alumni & $\begin{array}{c}\text { In-school } \\
\text { senior students }\end{array}$ & Alumni & & \\
\hline \multicolumn{9}{|c|}{ Knowledge about environmental sustainability } \\
\hline $\begin{array}{l}\text { I know about environmental sus- } \\
\text { tainability (Five-point scale) }\end{array}$ & $56.34 \%$ & $46.39 \%$ & $30.98 \%$ & $34.34 \%$ & $12.68 \%$ & $19.27 \%$ & 6.89 & $<0.05$ \\
\hline \multicolumn{9}{|c|}{ Identify the term which does NOT associate with environmental sustainability (Multiple choice) } \\
\hline Answer correctly & $62.68 \%$ & $57.23 \%$ & & & & & & \\
\hline Answer incorrectly & $37.32 \%$ & $42.77 \%$ & & & & & & \\
\hline \multicolumn{9}{|c|}{ Identify the term which DOES associate with environmental sustainability (Multiple choice) } \\
\hline Answer correctly & $73.24 \%$ & $76.51 \%$ & & & & & & \\
\hline Answer incorrectly & $26.76 \%$ & $23.49 \%$ & & & & & & \\
\hline \multicolumn{9}{|c|}{ Willingness to participate in environmental sustainability practices } \\
\hline I will use recycling & $76.06 \%$ & $75.90 \%$ & $18.31 \%$ & $14.46 \%$ & $5.63 \%$ & $9.64 \%$ & 16.93 & $<0.01$ \\
\hline $\begin{array}{l}\text { I will adapt to energy } \\
\text { conservation practices }\end{array}$ & $74.65 \%$ & $66.26 \%$ & $15.49 \%$ & $24.70 \%$ & $9.86 \%$ & $9.04 \%$ & 14.05 & $<0.01$ \\
\hline $\begin{array}{l}\text { I will use environmentally } \\
\text { friendly products }\end{array}$ & $75.35 \%$ & $70.48 \%$ & $13.38 \%$ & $25.30 \%$ & $11.27 \%$ & $4.22 \%$ & 15.82 & $<0.01$ \\
\hline I will use green transportation & $64.79 \%$ & $63.86 \%$ & $24.65 \%$ & $28.31 \%$ & $10.56 \%$ & $7.83 \%$ & 10.73 & $<0.01$ \\
\hline
\end{tabular}

products. As far as green transportation, $64.79 \%$ of the in-school seniors and $63.86 \%$ of the alumni express their support.

Overall, in-school senior students and alumni have similar level of perceived competence as reflected by their level of knowledge and willingness to engage in environmental sustainability.

\section{Demographic Effects on Environmental Sustainability}

To examine the effects of different demographic characteristics on the three sections environmental sustainability perceived by in-school senior students and alumni separately, a multivariate analysis of variance (MANOVA) was implemented. The results shown in

Table 6. Demographic effects on environmental sustainability by using MANOVA.

\begin{tabular}{|c|c|c|c|}
\hline Demographic & Pillai's Trace & F-statistics & p-value \\
\hline \multicolumn{4}{|c|}{ In-school senior students $(\mathrm{N}=142)$} \\
\hline Gender & 0.085 & 1.769 & 0.135 \\
\hline Major & 0.977 & 6.355 & 0.000 \\
\hline \multicolumn{4}{|c|}{ Alumni $(\mathrm{N}=166)$} \\
\hline Gender & 0.247 & 2.699 & 0.038 \\
\hline Major & 0.465 & 2.735 & 0.029 \\
\hline
\end{tabular}

Table 6 indicate that, for the in-school senior students' sample, respondents with different business majors (Pillai' Trace $=0.977$, F-statistics $=6.355$, p-value $=0.000$ ) were found to have significantly different perceptions toward environmental sustainability, whereas respondents of different gender (Pillai' Trace $=0.085$, F-statistics $=1.769, \mathrm{p}$-value $=0.135$ ) have no statistically different perceptions. In terms of the alumni counterpart, respondents with different gender (Pillai' Trace $=0.247$, F-statistics $=2.699$, p-value $=0.038$ ) and major (Pillai' Trace $=0.465$, F-statistics $=2.735$, $\mathrm{p}$-value $=0.029)$ were both found to have significantly different perceptions toward environmental sustainability.

\section{Discussion}

Given that in-school students and alumni are embedded in different institutional cultures and environments where university or company may exert different influences on individual's intention toward a particular behavior, we expect that their perception of environmental sustainability may also vary to some extent. As shown in Table 7, the mean value of inschool senior students for the three evaluation sections of environmental sustainability including attitude, subjective norm, and perceived behavioral control are all lower than that of alumni, indicating that in-school students generally exhibit a higher perceived value toward environmental sustainability. 
Table 7. Comparison of Environmental sustainability perceived by in-school students and alumni.

\begin{tabular}{|c|c|c|c|c|c|}
\hline \multirow{2}{*}{$\begin{array}{c}\text { Section of environmental } \\
\text { sustainability }\end{array}$} & \multicolumn{2}{|c|}{ Mean } & \multirow{2}{*}{$t$} & $\begin{array}{c}\text { Coefficient of variation between } \\
\text { in-school senior students and alumni }\end{array}$ \\
\cline { 2 - 3 } & In-school senior students & Alumni & & $\rho$ & $4.43 \%$ \\
\hline Attitude & 2.15 & 2.29 & -3.06 & $<0.01$ & $8.66 \%$ \\
\hline Subjective norm & 2.32 & 2.62 & -4.35 & $<0.01$ & $2.42 \%$ \\
\hline Perceived behavioral control & 2.08 & 2.15 & 2.26 & $<0.05$ & \\
\hline
\end{tabular}

The coefficient of variation between in-school senior students and alumni is further examined to assess the dispersion of mean value for the three evaluation sections of environment sustainability. The results in Table 7 reveal that the subjective norm section has the highest coefficient of variation. Compared with alumni, in-school students may feel more pressures from external groups who frequently interact with them such as university administrators, faculty and professors.

The possible reason of the highest level of subjective norm perceived by in-school senior students is that their personal attitude toward environmental sustainability may be routinely impacted by the everyday campus practices and their understanding of green issues may also reflect regular instructions and lectures by the university administration and academic supervisors $[20,76]$. As proposed by the legitimacy theory, students' behaviors are shaped by their perception of what other people do in support of a particular action, rules, or belief [62]. When a HEI actively involves in environmental sustainability initiatives such as the reduction of energy usage, the use of green transportation, and the incorporation of environmental sustainability issues into degree programs and courses, these support programs can legitimize environmental sustainability practices for the students. University students will therefore recognize such legitimacy that more likely align with the behavioral norms represented by environmental sustainability initiatives of their institution.

Furthermore, external groups which affect in-school students' mindset may traditionally occupy higher position in a hierarchy of HEIs [77]. The top-down legitimacy process can be referred to authorization, which emphasizes the support of a particular rule or action from authorities. Students will have their personal beliefs on environmental sustainability that differ from university policies and practices, but they still recognize that the authority supports a particular norm, and hence may adjust their own behaviors to follow the norm [73]. Even if in-school students may not directly benefit from such green practices, they can have less sanctions formally imposed by the administration [78].

To further analyze the extent to which external referent groups affect students' perception toward environmental sustainability, we examine both mean value and coefficient of variation for in-school senior students and alumni in terms of three types of influencers including university administration, faculty and professors, and business leaders and colleagues. The results are shown in Table 8 . Given that inschool seniors assign a lower mean value with respect to the influence of university administration and faculty and professors, they may feel more pressure that administratively and academically arise from the university initiatives as compared to alumni who are no more a part of the academic setup. In addition, the influence of faculty and professors have the highest value of coefficient of variation, asserting that there is a greatest variability in in-school seniors and alumni's opinion regarding the perceived pressure from the academic staff.

Since that in-school students consider they may receive more positive influence from the HEIs, their perception can be transformed into action if the university perceives environmental sustainability as essential and the campus itself become environmentally responsible [76]. When a particular norm or behavior is valid, in-school students may realize its legitimate status and likewise support it. In the context of perceived legitimacy, we develop two implications for HEIs to enhance students' perception about environmental sustainability. First, because individuals may follow a norm or a behavior if they regard it as an obligation, HEIs' environmental sustainability initiatives can be implemented through authorization of a set of

Table 8. Comparison of subjective norm perceived by in-school students and alumni.

\begin{tabular}{|c|c|c|c|c|c|}
\hline \multirow{2}{*}{$\begin{array}{c}\text { Referent groups that give pressures to } \\
\text { students }\end{array}$} & \multicolumn{2}{|c|}{ Mean } & \multirow{2}{*}{$t$} & $\begin{array}{c}\text { Coefficient of variation } \\
\text { between in-school senior } \\
\text { students and alumni }\end{array}$ \\
\cline { 2 - 5 } & In-school senior students & Alumni & & & $9.38 \%$ \\
\hline University administration & 2.35 & 2.69 & -2.37 & $<0.05$ & $12.15 \%$ \\
\hline Faculty and professors & 2.31 & 2.75 & -3.59 & $<0.01$ & $3.53 \%$ \\
\hline Business leaders and colleagues & 2.26 & 2.37 & 2.26 & $<0.05$ & 9.38 \\
\hline
\end{tabular}


rules or guidelines which all the campus stakeholders must adhere to promote environmental sustainability. Furthermore, administrators need to clarify their leadership in building a culture of environmental sustainability and set forth some policies in relation to campus's environmental management, green infrastructure and transportation. Likewise, faculty and professors can actively educate their students regarding the possible solutions for the current environmental issues. Second, HEIs can advocate best sustainability practices of their peers because individuals may also comply with a norm if they find peers are also following similar practices.

Though alumni are less impacted by the university administrators and professors, they will be considerably influenced by the firms' economic and sustainability objectives. In fact, executives usually like to pursue short-term profit maximization goals, considering that the efforts toward environmental sustainability may go against the core objective of a corporation. Environmental education can enhance students' sensitivity toward environmental issues to some extent [17], yet it is only one step to champion environmentally responsible practices because there is no assurance that alumni will follow sustainable practices once they practically enter the business world. However, as an important influencer for alumni, business leaders and executives need to recognize and promote the legitimacy of environmental sustainability and integrate greener elements into managerial decision-making process.

\section{Conclusions}

Higher education institutions (HEIs) are the crucial drivers of change in achieving environmental sustainability because education can shape the behavior of the next generation of leaders and mangers that affect business context and communities at large. In recent years, business schools were criticized for their inadequate integration of environmental management into education and campus operation [6,79]. A win for the environment does not traditionally comply with firms' profit maximization, and may generate a challenge for business educators in fostering students' sense of personal responsibility for green management practices. To assess whether business students champion environmental sustainability, this study explores both in-school students and alumni's perception because their capacity is a reflection of the pedagogical achievements of their institution.

By employing the theory of planned behavior (TPB) model, three evaluation sections consisting of attitude, subjective norm, and perceived behavioral control are used to examine environmental sustainability perceived by the in-school students (undergraduate seniors) and the already graduated students (alumni). The results reveal that students ranked external referent groups (subjective norm) as the most important factor, followed by personal beliefs (attitude) and perceived competence for engaging in the environmentally sustainable behavior (perceived behavioral control). Compared with the alumni, the in-school students have a more favorable perception in all three evaluation sections. Besides, the biggest perception gap between the in-school students and alumni is in the subjective norm section where in-school students more often agreed to the importance of university administrators and professors as a valid referent group in promoting environmental sustainability. The current study contributes to existing literature as there are not many papers addressing whether sustainability education outcome can meet the requirement of real-world scenario. We particularly explore alumni's perceived environmental sustainability, which is less examined in previous studies because existing research largely focused on in-school students and other stakeholders inside university campus.

We provide some implications for both educators and corporate leaders. Given that in-school students' value and belief may be significantly shape by HEIs, and they are also academically and residentially located at the campus, HEIs may play a vital role in driving environmental sustainability for next generation of leaders. This could be achieved by mandating environmentally responsible policies in the campus, and introducing more sustainability issues into the curriculum and the classroom. For corporate practitioners, they need to exercise their management discretion to seek for a balance between environmental responsibility and economic performance of a firm, given their sustainability attitudes also substantially affect already graduated students' practical business work connected to environmental sustainability.

With regards to the limitations of our current work, we do not include all possible items to thoroughly measure individual's perceived environmental sustainability. Future study could therefore consider the influence from other referent groups like parent and media. Moreover, we only administrate survey to two different business majors, thus exerting some bias to represent all business students with different degree programs. Future research could survey students from natural science majors, and shed light on other stakeholders of HEIs such as academic staffs, educational administrators, and job providers. Further research may also extend to comparative analysis with different geographical and disciplinary contexts. 


\section{Appendices}

\section{Appendix A.1}

Environmental sustainability questionnaire surveyed to in-school students and alumni

\section{Attitude}

1. I am quite concerned at present about the wasteful consumption of natural resources and the destruction/pollution of the environment

2. I believe that the protection of the environment is more important than economic growth

3. I believe that we must conserve our resources for future generations of people

\section{Subjective Norm}

\section{a. University administration}

4. University should engage environmental sustainability into campus planning, development and day-to-day operations

5. University should contribute to energy conservation practices

6. University should contribute to recycling of solid waste

7. University should contribute to water conservation practices

8. University should contribute to green transportation program

\section{b. Faculty and professors}

9. Professors need to integrate some environmental sustainability aspects into courses

10. Faculty need to offer courses which address topic related to environmental sustainability

11. Faculty need to promote research related to environmental sustainability

\section{c. Business leaders and colleagues}

12. Company should represent itself as environmentally friendly

13. Company should contribute to energy and resource conservation practices

14. Company should contribute to energy and resource conservation practices

\section{Perceived behavioral control}

\section{a. Knowledge about environmental sustainability}

15. I know about environmental sustainability (Five-point scale)

16. Identify the term which does NOT associate with environmental sustainability (Multiple choice)

a) Wind turbines; b) Solar energy; c) Biomass; d) Nuclear energy

17. Please identify the term in the following group that you DO associate with environmental sustainability (Multiple choice)

a) Putting papers in the trashcan;

b) Not letting the water run while brushing the teeth;

c) Acquiring and managing human resources effectively and efficiently;

d) Ensuring customer safety in using goods and services

\section{b. Willingness to participate in environmental sustainability practices}

18. I will use recycling

19. I will adapt to energy conservation practices

20. I will use environmentally friendly products

21. I will use green transportation 


\section{Acknowledgements}

This work was supported by the Post Doc Research Program in University of Hradec Kralove, and the Excellent PhD Research Project in Guangzhou College of South China University of Technology [grant number 2019035BGS].

\section{Conflict of Interest}

The authors declare no conflict of interest.

\section{References}

1. United Nations Educational, Scientific and Cultural Organization (UNESCO). Shaping the Future We Want - UN Decade of Education for Sustainable Development (Final report). Paris: UNESCO. 2014.

2. QURESHI M.I., QAYYUM S., NASSANI A.A., ALDAKHIL A.M., ABRO M.M.Q., ZAMAN K. Management of various socio-economic factors under the United Nations sustainable development agenda. Resour. Policy, 64, 101515, 2019.

3. WANG J., YANG M., MARESOVA P. Sustainable Development at Higher Education in China: A Comparative Study of Students' Perception in Public and Private Universities. Sustainability, 12, 2158, 2020.

4. World Commission on Environment and Development (WCED). Our common future: Oxford University Press: Oxford, 1987.

5. CHRISTIE B.A., MILLER K.K., COOKE R., WHITE, J.G. Environmental sustainability in higher education: how do academics teach? Environ. Educ. Res., 19 (3), 385, 2013.

6. THOMAS T.E. Are business students buying it? A theoretical framework for measuring attitudes toward the legitimacy of environmental sustainability. Bus. Strate. Environ., 14 (3), 186, 2005.

7. DZHENGIZ T., NIESTEN E. Competences for environmental sustainability: A systematic review on the impact of absorptive capacity and capabilities. J. Bus. Ethics, 162 (4), 881, 2020.

8. VINCENZI S.L., POSSAN E., DE ANDRADE D.F., PITUCO M.M., DE OLIVERIRA STANTOS T., JASSE E.P. Assessment of environmental sustainability perception through item response theory: A case study in Brazil. J. Clean. Prod., 170, 1369, 2018.

9. ZHU Q., LIU J., LAI K. Corporate social responsibility practices and performance improvement among Chinese national state-owned enterprises. Int. J. Prod. Econ., 171, 417, 2016.

10. LONG W., LI S., WU H., SONG X. Corporate social responsibility and financial performance: The roles of government intervention and market competition. Corp. Soc. Resp. Env. Ma., 27 (2), 525, 2020

11. CAI S., CHEN X., BOSE I. Exploring the role of IT for environmental sustainability in China: An empirical analysis. Int. J. Prod. Econ., 146 (2), 491, 2013.

12. YUAN X., ZUO J. A critical assessment of the sustainable university from students' perspectives e a Chinese study. J. Clean. Prod., 48, 108-, 2013.
13. ANDERSSON P., ÖHMAN J. Logics of business education for sustainability. Environ. Educ. R., 22 (4), 463, 2016.

14. DZURANIN A.C., SHORTRIDGE R.T., SMITH P.A. Building ethical leaders: A way to integrate and assess ethics education. J. Bus. Ethics, 115 (1), 101, 2013.

15. World Resources Institute. Beyond Grey Pinstripes: Preparing MBAs for Social and Environmental Stewardship. 2003 [cited 202006 June]; Available from: https://assets.aspeninstitute.org/content/uploads/files/ content/upload/bgps_2003_brochure.pdf, 2003.

16. HAY R., EAGLE L. Impact of integrated sustainability content into undergraduate business education. Int. J. Sust. Higher Ed., 21 (1), 131, 2020.

17. CULLEN J.G. Educating business students about sustainability: A bibliometric review of current trends and research needs. J. Bus. Ethics, 145 (2), 429, 2017.

18. EMANUEL R., ADAMS J.N. College students' perceptions of campus sustainability. Int. J. Sust. Higher Ed., 12 (1), 79, 2011

19. SWAIM J.A., MALONI M. J., NAPSHIN S.A., Henley A. B. Influences on Student Intention and Behavior Toward Environmental Sustainability. J. Bus. Ethics, 124 (3), 465 , 2013.

20. DAGILIŪTÉ R., LIOBIKIENĖ G., MINELGAITÉ A. Sustainability at universities: Students' perceptions from Green and Non-Green universities. J. Clean. Prod., 181, 473, 2018.

21. BLICKLEY J.L., DEINER K., GARBACH K., LACHER I., MEEK M.H., PORENSKY L.M., WILKERSON, M.L., WINFORD, E.M., SCHWARTZ, M.W. Graduate student's guide to necessary skills for nonacademic conservation careers. Conserv. Biol., 27 (1), 24, 2013.

22. MACDONALD L., SHRIBERG M. Sustainability leadership programs in higher education: alumni outcomes and impacts. J Environ Stud Sci, 6 (2), 360, 2016.

23. BERTACCINI B., BACCI S., PETRUCCI A. A graduates' satisfaction index for the evaluation of the university overall quality. Socio Econ. Plan. Sci., 100875, 2020.

24. HESSELBARTH C., SCHALTEGGER S. Educating change agents for sustainability - learnings from the first sustainability management master of Business Administration. J. Clean. Prod., 62 (1), 24, 2014.

25. WEI Z., SHEN H., ZHOU K.Z., LI J.J. How Does Environmental Corporate Social Responsibility Matter in a Dysfunctional Institutional Environment? Evidence from China. J. Bus. Ethics, 140 (2), 209, 2017.

26. WU J. The Antecedents of Corporate Social and Environmental Irresponsibility. Corp. Soc. Resp. Env. Ma., 21 (5), 286, 2014.

27. SHAN S., PENG J., WEI Y. Environmental Sustainability assessment 2.0: The value of social media data for determining the emotional responses of people to river pollution - A case study of Weibo (Chinese Twitter). Socio Econ. Plan. Sci., 100868, 2020.

28. CONNER M., ARMITAGE C.J. Extending the theory of planned behavior: A review and avenues for further research. J. Appl. Soc. Psychol., 28 (15), 1429, 1998.

29. AJZEN I. The theory of planned behavior. Organ. Behav. Hum. Decis. Process, 50 (2), 179, 1991.

30. WU Y.C.J., SHEN J.P., KUO T. An overview of management education for sustainability in Asia. Int. J. Sust. Higher Ed., 16 (3), 341, 2015.

31. RAHMAN A.A., CASTKA P., LOVE T. Corporate social responsibility in higher education: A study of 
the institutionalisation of CSR in Malaysian public universities. Corp. Soc. Resp. Env. Ma., 26 (4), 916, 2019.

32. University Leaders for a Sustainable Future. Talloires declaration institutional signatory list. 2020 [cited 202006 June]; Available from: http://ulsf.org/96-2/, 2020.

33. WALS A.E.J., BLEWITT J. Third-wave sustainability in higher education: Some (inter)national trends and developments. In Sustainability Education: Perspectives and Practice across Higher Education; Jones P., Selby D., Sterling S. (Eds.), Earthscan: London, 55, 2010.

34. FIGUEIRO P.S., RAUFFLET E. Sustainability in higher education: a systematic review with focus on management education. J. Clean. Prod., 106, 22, 2015.

35. ERSKINE L., JOHNSON S.D. Effective learning approaches for sustainability: A student perspective. J. Educ. Bus., 87 (4), 198, 2012.

36. CHRISTIE B.A., MILLER K.K., COOKE R., WHITE J.G. Environmental sustainability in higher education: What do academics think? Environ. Educ. Res., 21 (5), $655,2015$.

37. BERCHIN I.I., DOS SANTOS GRANDO V., MARCON G.A., CORSEUIL L., DE ANDRADE J.B.S.O. Strategies to promote sustainability in higher education institutions. Int. J. Sust. Higher Ed., 18 (7), 1018, 2017.

38. BIZERRIL M., ROSA M.J., CARVALHO T., PEDROSA J. Sustainability in higher education: A review of contributions from Portuguese Speaking Countries. J. Clean. Prod., 171, 600, 2018.

39. EARL A., VANWYNSBERGHE R., WALTER P., STRAKA T. Adaptive education applied to higher education for sustainability. Int. J. Sust. Higher Ed., 19 (6), 1111, 2018.

40. ISLAM T., ALI G., ASAD H. Environmental CSR and pro-environmental behaviors to reduce environmental dilapidation. MANAG. REV RES., 42 (3), 332, 2019.

41. MOUSA M., ABDELGAFFAR H.A., AYOUBI R. M. Responsible management education in Egyptian public business schools. J. Manag. Dev., 38 (8), 681, 2019.

42. BROOKES M., ALTINAY L., RINGHAM K. Successful implementation of responsible business practice. Worldw. Hosp. Tour. Themes, 6 (1), 77, 2014.

43. United Nations Principles for Responsible management (UNPRME). What is PRME. 2007 [cited 202006 June]; Available from: https://www.unprme.org/about, 2007.

44. AACSB (The Association to Advance Collegiate Schools of Business) International. Globalization of Management Education: Changing International Structures, Adaptive Strategies, and the Impact on Institutions. 2011 [cited 2020 06 June]; Available from: https://www.aacsb.edu/-/media/ aacsb/publications/research-reports/aacsb-globalizationof-management-education-task-force-report-2011.ashx?la= en\&hash $=46 \mathrm{~B} 805416 \mathrm{C} 12 \mathrm{C} 419 \mathrm{DCFEE} 8 \mathrm{FC} 4 \mathrm{C} 36 \mathrm{DBCB} 3 \mathrm{~A}$ E2519A, 2011.

45. European Foundation for Management Development (EFMD). EPAS Standards and Criteria. 2019 [cited 2020 06 June]; Available from: https://www.efmdglobal.org/wpcontent/uploads/EFMD_Global_EPAS_Standards_and Criteria.pdf, 2019.

46. PERERA C.R., HEWEGE C.R. Integrating sustainability education into international marketing curricula. Int. J. Sustain. High. Educ., 17 (1), 123, 2016.

47. WYMER W., RUNDLE-THIELE S.R. Inclusion of ethics, social responsibility, and sustainability in business school curricula: a benchmark study. Int. Rev. Public Nonprofit Mark., 14 (1), 19, 2017.
48. SIDIROPOULOS E. Education for sustainability in business education programs: a question of value. J. Clean. Prod., 85, 472, 2014.

49. NAEEM M., NEAL M. Sustainability in business education in the Asia Pacific region: a snapshot of the situation. Int. J. Sustain. High. Educ., 13 (1), 60, 2012.

50. Higher Education Funding Council for England (HEFCE). Sustainable development in higher education. 2005 [cited 202006 June]; Available from: https://dera.ioe. ac.uk/5196/1/05 01.pdf, 2005.

51. CEULEMANS K., DE PRINS M., CAPPUYNS V., CONINCK W. Integration of sustainable development in higher education's curricula of applied economics: Largescale assessments, integration strategies and barriers. J. Manag. Organ., 17 (5), 621, 2011.

52. LITTLEDYKE M., MANOLAS E. Ideology, Epistemology and Pedagogy: Barriers and Drivers to Education for Sustainability in Science Education. J. Balt. Sci. Educ., 9, $285,2010$.

53. COTTON D., WINTER J. 'It's not just bits of paper and light bulbs': A review of sustainability pedagogies and their potential for use in higher education. In Sustainability Education: Perspectives and Practice across Higher Education; Jones P., Selby D., Sterling S. (Eds.), Earthscan: London, 39, 2010.

54. ULL M.A., MARTÍNEZ-AGUT M.P., PIÑERO A., AZNAR-MINGUET P. Perceptions and Attitudes of Students of Teacher-training towards Environment and Sustainability. Procedia Soc. Behav. Sci., 131, 453, 2014.

55. HILLER C.K.Y., KOZAR J.M. Sustainability knowledge and behaviors of apparel and textile undergraduates. Int. J. Sustain. High. Educ., 13 (4), 394, 2012.

56. YU T.Y., YU T.K., CHAO C.M. Understanding Taiwanese undergraduate students' pro-environmental behavioral intention towards green products in the fight against climate change. J. Clean. Prod., 161, 390, 2017

57. BAHAEE M., PEREZ-BATRES L.A., PISANI M. J., MILLER V.V., SAREMI M. Sustainable Development in Iran: An Exploratory Study of University Students' Attitudes and Knowledge about Sustainable Development. Corp. Soc. Responsib. Environ. Manag., 21 (3), 175, 2012.

58. WITOSZEK N. Teaching sustainability in Norway, China and Ghana: challenges to the UN programme. Environ. Educ. Res., 24 (6), 831, 2017.

59. YUAN X., ZUO J., HUISINGH D. Green Universities in China - what matters? J. Clean. Prod., 61, 36, 2013.

60. China Green University Network (CGUN). Introduction to China Green University Network. 2011 [cited 202006 June]; Available from: http://www.cgun.org.cn/en/content. aspx?info_lb=107\&flag=1, 2011.

61. TIAN Y., WANG C. Environmental education in China: Development, difficulties and recommendations. J. Soc. Sci. Stud., 3 (1), 31, 2016.

62. SUCHMAN M. Managing legitimacy: strategic and institutional approaches. Acad. Manage. Rev., 20 (3), 571, 1995.

63. DORNBUSCH S.M. Evaluation and the Exercise of Authority (The Jossey-Bass behavioral science series), 1st ed.; Jossey-Bass Inc Pub: San Francisco, 1975.

64. OZTEKIN C., TEKSOZ G., PAMUK S., SAHIN E., KILIC D.S. Gender perspective on the factors predicting recycling behavior: Implications from the theory of planned behavior. Waste Manage., 62, 290-302, 2017.

65. LAKHAN C. The garbage gospel: Using the theory of planned behavior to explain the role of religious institutions 
in affecting pro-environmental behavior among ethnic minorities. J. Environ. Educ. 49 (1), 43, 2018.

66. LIOBIKIENE G., MANDRAVICKAITE J., BERNATONIENE J. Theory of planned behavior approach to understand the green purchasing behavior in the EU: A cross-cultural study. Ecol. Econ., 125, 38, 2016.

67. YADAV R., PATHAK G.S. Determinants of consumers' green purchase behavior in a developing nation: Applying and extending the theory of planned behavior. Ecol. Econ., 134, 114, 2017.

68. HO S.S., LIAO Y., ROSENTHAL S. Applying the theory of planned behavior and media dependency theory: Predictors of public pro-environmental behavioral intentions in Singapore. Environ. Commun., 9 (1), 77, 2015.

69. DE LEEUW A., VALOIS P., AJZEN I., SCHMIDT P. Using the theory of planned behavior to identify key beliefs underlying pro-environmental behavior in highschool students: Implications for educational interventions. J. Environ. Psychol., 42, 128, 2015.

70. AJZEN I., FISHBEIN M. Understanding attitudes and predicting social behavior; Prentice-Hall: Englewood Cliffs, 1980

71. DE LEEUW A., VALOIS P., AJZEN I., SCHMIDT P. Using the theory of planned behavior to identify key beliefs underlying pro-environmental behavior in highschool students: Implications for educational interventions. J. Environ. Psychol., 42, 128, 2015.

72. NOTANI A.S. Moderators of perceived behavioral control's predictiveness in the theory of planned behavior: A meta- analysis. J. Consum. Psychol., 7 (3), 247, 1998.
73. THOMAS T.E., LAMM E. Legitimacy and Organizational Sustainability. J. Bus. Ethics, 110 (2), 191, 2012.

74. ZELDITCH M., WALKER H.A. Legitimacy and the stability of authority. Adv. Group Process., 1, 1, 1984.

75. ZHANG X., WEN D., LIANG J., LEI J. How the public uses social media wechat to obtain health information in china: a survey study. BMC Medical Inform. Decis. Mak., 17 (2), 71, 2017.

76. LIU L., WIE K., ZHANG X., WEN D., GAO L., LEI J. The Current Status and a New Approach for Chinese Doctors to Obtain Medical Knowledge Using Social Media: A Study of WeChat. Wirel. Commun. Mob. Comput., 2018, $1,2018$.

77. SNELSON-POWELL A., GROSVOLD J., MILLINGTON A. Business school legitimacy and the challenge of sustainability: A fuzzy set analysis of institutional decoupling. Acad. Manag. Learn. Educ., 15 (4), 703, 2016.

78. WATSON L., HEGTVEDT K.A., JOHNSON C., PARRIS C.L., SUBRAMANYAM S. When Legitimacy Shapes Environmentally Responsible Behaviors: Considering Exposure to University Sustainability Initiatives. Educ. Sci., 7(1), 13, 2017.

79. TYLER T.R., JCAKSON J. Popular legitimacy and the exercise of legal authority: Motivating compliance, cooperation, and engagement. Psychol. Public Policy, Law, 20 (1), 78, 2014.

80. WRIGHT N.S., BENNETT H. Business ethics, CSR, sustainability and the MBA. J. Manag. Organ., 17 (5), 641, 2011. 